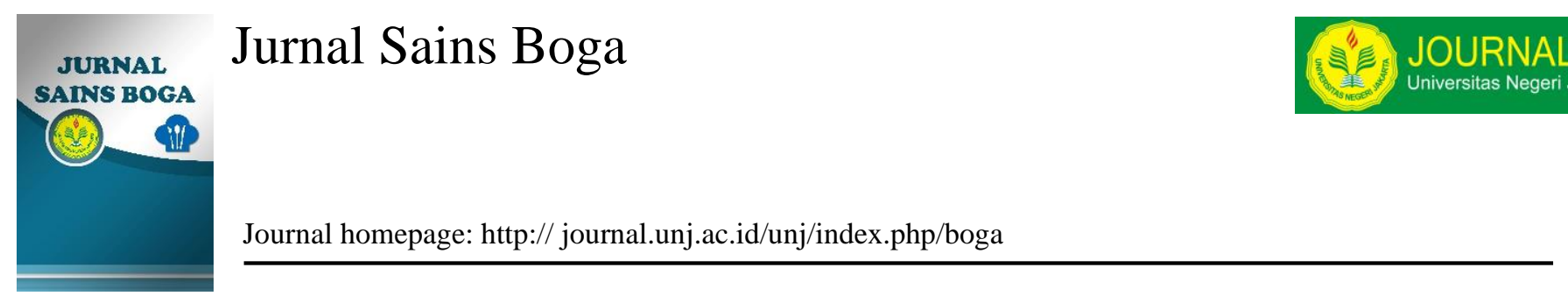

\title{
Model Pelatihan Higiene Sanitasi Bagi Penjamah Makanan
}

\author{
Sri Handajani \\ Prodi Tata Boga, Fakultas Teknik, Universitas Negeri Surabaya \\ Email: srihandajani@unesa.ac.id
}

\begin{abstract}
ABSTRAK
Penelitian ini bertujuan untuk mengetahui: 1) kepraktisan model pelatihan dan 2) Keefektifan pelatihan meliputi aktifitas instruktur, aktifitas dan respon peserta pelatihan serta peningkatan pengetahuan, sikap dan praktik higiene penjamah makanan. Penelitian pengembangan ini mengacu pada model Plomp (1997) yang terdiri dari empat tahap, yaitu tahap pengkajian awal (preliminary investigation), tahap disain (design), tahap realisasi (realization), dan tahap tes, evaluasi, dan revisi (test, evaluation, and revision). Uji coba pelatihan dilaksanakan di Foodcourt Baseball Unesa Ketintang Surabaya. Hasil penelitian ini menunjukkan: 1) Evaluasi kepraktisan model diperoleh model pelatihan yang memenuhi kriteria sangat valid $(4,28)$ dan layak digunakan, serta handout dengan kriteria baik sekali $(86,19 \%)$; 2) Hasil penilaian aktifitas instruktur baik sekali dan $96 \%$ peserta pelatihan mengikuti kegiatan pelatihan dengan baik; 89\% peserta pelatihan memberikan respon senang terhadap kegiatan pelatihan; Pelatihan secara signifikan efektif terhadap peningkatan pengetahuan, praktik berperilaku higienis, dan sikap penjamah makanan.
\end{abstract}

Kata Kunci : model pelatihan, higiene, sanitasi, penjamah makanan

\section{PENDAHULUAN}

Makanan yang aman dan sehat diperoleh dengan melaksanakan praktik higienis dalam proses produksi makanan. Praktik higienis penjamah makanan dimaksudkan untuk menghindari kerusakan makanan dan penurunan kualitas makanan mulai dari bahan mentah hingga menjadi makanan yang siap untuk dimakan. Praktik higienis merupakan bagian dari higiene sanitasi makanan yang bertujuan untuk pengawasan dan pencegahan makanan agar tidak terkontaminasi bakteri, baik secara langsung maupun tidak langsung.

Menurut National Health and Medical Research Council (NHMRC) [1], penanganan makanan yang baik pada semua tahapan penyiapan dan penyimpanan makanan dapat mengurangi insiden atau kejadian penyakit bawaan makanan. Penyakit bawaan makanan dapat muncul pada individu karena terjadinya kontaminasi pada makanan yang dapat disebabkan oleh faktor fisik, mikro, makro, dan kimia.

Kontaminasi makanan terjadi pada setiap titik selama proses penyajian makanan mulai dari produksi bahan makanan, pengolahan, distribusi, dan penyajian [2], [3]. Risiko kejadian penyakit akibat makanan yang terkontaminasi bergantung pada status kesehatan, kebersihan pribadi, pengetahuan, dan praktik kebersihan makanan dari penjamah makanan [4]. Kontaminan masuk ke dalam makanan diantaranya melalui tangan penjamah makanan yang kotor, serangga, dan udara [5]. 
Penjamah makanan (food handler), yaitu setiap orang yang menangani makanan serta berperan penting dalam perpindahan dan pencegahan penyakit akibat makanan [5]. Praktik higienis penjamah makanan adalah kunci sukses untuk mengatasi peningkatan penyakit yang disebabkan oleh makanan. Beberapa tahun terakhir, pengaruh perubahan gaya hidup dan peningkatan jumlah wanita bekerja menyebabkan peningkatan konsumsi makanan di luar rumah. Setiap orang mungkin mampu memuaskan selera dan kebutuhan nutrisi mereka dengan membeli makanan, tetapi sedikit sekali yang mau memperhatikan kebersihan dan keamanan pangan [6].

Makanan yang tidak aman merupakan sumber penyebab penyakit akibat makanan. Sebagian besar penyebab penyakit bawaan makanan berasal dari mikroorganisme, seperti bakteri, parasit, ataupun bahan kimia. BPOM RI [7] melaporkan bahwa kejadian luar biasa (KLB) keracunan pangan di Indonesia, $13.21 \%$ disebabkan mikroba terkonfirmasi, $45.28 \%$ dugaan mikroba, $7.55 \%$ diduga oleh kimia, $5.66 \%$ oleh kimia terkonfirmasi, dan $28.30 \%$ lainnya tidak diketahui penyebabnya. Wabah penyakit bawaan makanan banyak berasal dari perusahaan pelayanan makanan [8], dan penyakit bawaan makanan dikaitkan dengan makanan yang berasal dari luar rumah [9],[10]. Agak berbeda dengan laporan BPOM RI [11] bahwa wabah penyakit bawaan makanan banyak disebabkan oleh masakan rumah tangga (40\%), jasa boga termasuk katering, foodcourt, dsb (35\%), makanan jajanan (16\%), dan selebihnya berasal dari makanan produksi dalam dan luar negeri serta restauran.

Makanan atau bahan makanan mentah terkontaminasi dan kebersihan pribadi penjamah makanan yang kurang baik merupakan faktor yang paling sering diidentifikasi sebagai penyebab wabah penyakit [12]. Perilaku penjamah makanan merupakan salah satu faktor yang menentukan keamanan makanan [13]. Makanan yang dikerjakan dengan kebersihan pribadi yang kurang menyumbang terjadinya wabah penyakit bawaan makanan [14], [8].

Undang-Undang No.18 tahun 2012 tentang pangan, telah menetapkan standar dan persyaratan agar makanan dan minuman layak serta aman untuk dikonsumsi masyarakat, yaitu pada pasal 71 ayat 1 dan 2 yang menjelaskan bahwa setiap orang yang terlibat dalam rantai pangan harus mengendalikan risiko bahaya pada pangan dan setiap orang yang melakukan proses penyiapan atau produksi makanan wajib memenuhi persyaratan higiene, sanitasi dan keamanan pangan. Untuk meningkatkan kualitas pelayanan dan mencegah terjadinya penyakit bawaan makanan, maka penjamah makanan harus mengetahui dan memahami perilaku higienis dalam mengelola makanan. Menurut Motarjemi dan Kaferstein [15], penjamah makanan terutama yang tidak atau belum mendapatkan pengetahuan higiene dan sanitasi, mereka berpotensi untuk mengontaminasi makanan dalam produksi makanan secara masal. Pelatihan kesehatan makanan merupakan upaya untuk meningkatkan praktik keamanan makanan pada penjamah makanan [16], di samping itu, kunci untuk mencegah penyakit yang berhubungan dengan makanan adalah pendidikan dan pelatihan bagi penjamah makanan [17]. 
Foodcourt baseball merupakan tempat yang mewadahi 20 stand penjual makanan di dalam kampus unesa ketintang surabaya yang dioperasikan sejak tahun 2012. Praktik berperilaku higienis (rata-rata 64\%) yang masih cenderung dilupakan atau jarang dilakukan oleh penjamah makanan seperti kebiasaan menggunakan celemek, menggunakan alat pengambil makanan secara khusus atau tidak memegang langsung makanan siap santap dengan tangan langsung, dan kebiasaan untuk melakukan cuci tangan dengan baik dan benar. Berdasarkan hasil pengamatan dan mempertimbangkan akan pentingnya memberikan penguatan hygiene dan sanitasi maka pelatihan higine dan sanitasi perlu dilakukan. Tujuan dari penelitian ini adalah mengetahui: 1) kepraktisan model pelatihan dan 2) keefektifan pelatihan meliputi aktifitas instruktur, aktifitas dan respon peserta pelatihan serta peningkatan pengetahuan, sikap dan praktik higiene penjamah makanan.

\section{METODE}

Penelitian ini merupakan penelitian pengembangkan mengacu pada model Plomp yang terdiri dari 4 model, yaitu 1) tahap pengkajian awal (menganalisis praktik higienis, kebutuhan pelatihan dengan melakukan Focus Group Discussion (FGD) pada penjamah makanan dan kelompok konsumen dan standar kemampuan minimal dan menganalisis karakteristik penjamah makanan); 2) tahap perancangan yang dilakukan: a) merancang sintaks pelatihan; b) merancang lingkungan belajar seperti peran instruktur dan aktivitas yang harus dilakukan oleh peserta pelatihan selama pelatihan berlangsung; c) merancang sistem pendukung, yaitu perangkat pelatihan (handout, silabus pelatihan, lembar assesmen), fasilitas belajar, media yang diperlukan dalam pelatihan; 3) Tahap realisasi/konstruksi dilakukan dengan menyusun model pelatihan higiene makanan bagi penjamah makanan sebagai lanjutan dari tahap desain, sehingga menghasilkan draft atau prototipe model yang disebutkan pada tahap perancangan; 4) Tahap tes, evaluasi, dan revisi difokuskan pada dua hal, yaitu memvalidasi model dan mengadakan uji coba lapangan draft atau prototipe tentang model pelatihan dan perangkat yang telah disusun.

Penelitian ini dilakukan di Foodcourt Baseball Unesa Ketintang Surabaya, pada penjamah makanan yang berjualan di area foodcourt tersebut. Teknik pengumpulan data yang dilakukan dalam penelitian ini adalah (1) metode Studi Pustaka; (2) wawancara; (3) dokumentasi; (4) observasi; (5) kuesioner (angket); Data yang terkumpul kemudian dianalisis secara deskriptif dengan penyajian data persentase, dan uji t.

\section{HASIL DAN PEMBAHASAN}

1. Tahap pengkajian awal

a. Berdasarkan gambaran pengamatan praktik higienis yang dilakukan oleh penjamah makanan yang ada di Foodcourt Baseball Unesa Ketintang Surabaya menunjukkan bahwa praktik higienis rata-rata cukup baik (64\%).

b. Secara keseluruhan kebersihan tangan cukup baik (51.07\%), meskipun belum semua penjamah makanan melakukan cuci tangan sebelum memulai bekerja atau pada saat tangan kotor.

c. Teknik identifikasi kebutuhan pelatihan yang menggunakan Focus Group Discussion (FGD). FGD dimaksudkan untuk menelusuri kebutuhan pelatihan secara kualitatif dengan cara memusatkan pada kebutuhan materi pelatihan dalam kelompok konsumen dan penjamah makanan. Berdasarkan hasil diskusi, kelompok konsumen sepakat mendukung keinginan dari kelompok penjamah makanan, bahwa perlunya diadakan pelatihan higiene makanan untuk meningkatkan pengetahuan, ketrampilan dan sikap dari penjamah makanan.

2. Tahap perancangan 


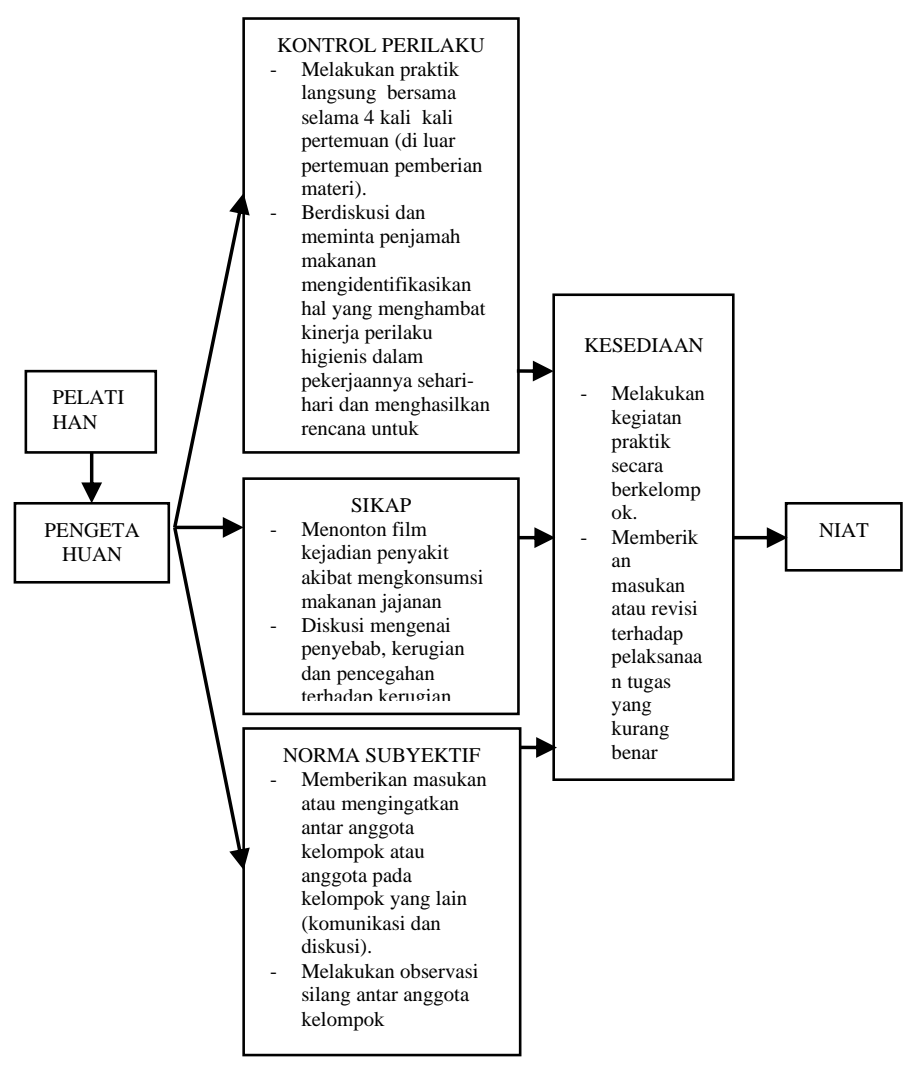

GAMBAR 1. Tahap Perancangan

3. Tahap realisasi

Tahap realisasi adalah kegiatan penyusunan draft 1 model dan perangkat pelatihan sesuai dengan format yang telah ditentukan.

a. Nama Program "Pelatihan Higiene Makanan bagi Penjamah Makanan di Foodcourt Baseball

Kampus Unesa Ketintang Surabaya." untuk meningkatkan pengetahuan, sikap, dan keterampilan penjamah makanan.

b. Tujuan program pelatihan untuk meningkatkan pengetahuan, sikap dan ketrampilan atau praktik berperilaku higienis.

c. Peserta pelatihan adalah penjamah makanan yang ada di Foodcourt Baseball Kampus Unesa Ketintang Surabaya.

d. Pelatihan dilaksanakan di joglo Foodcourt Baseball Kampus Unesa Ketintang Surabaya yang letaknya berdampingan dengan tempat berjualan para penjamah makanan. Kegiatan dilaksanakan pada hari libur sedangkan kegiatan pendampingan dan praktik dilaksanakan pada hari kerja efektif, pelaksanaannya 1 minggu sekali selama 4 kali pertemuan.

e. Silabus pelatihan berisi materi, waktu, tujuan umum, tujuan khusus, subpokok bahasan, metode, media, dan alat bantu yang digunakan. Dalam kegiatan pelatihan higiene makanan yang akan dilakukan, materi yang diberikan adalah higiene makanan. Materi disusun dengan sedemikian rupa agar waktu penyampaian tidak terlalu panjang dan kegiatan dapat lebih banyak mengarah pada praktik.

4. Tahap tes, evaluasi dan revisi

Berdasarkan kriteria penilaian yang sudah ditentukan, model pelatihan yang dikembangkan termasuk dalam katagori valid karena memenuhi validitas konstruk dan validitas isi. 
TABEL 1. Validitas Konstruk Dan Validitas Isi

\begin{tabular}{|c|c|c|c|c|}
\hline Komponen & $\begin{array}{c}\text { Hasil } \\
\text { Analisis }\end{array}$ & Sebelum Revisi & Keputusan & Setelah Revisi \\
\hline $\begin{array}{l}\text { Model } \\
\text { pelatihan }\end{array}$ & $\begin{array}{l}\text { Validasi } \\
\text { Rata-rata } \\
(\mathrm{VR})=4,28\end{array}$ & $\begin{array}{l}\text { a. Kompetensi utama } \\
\text { (KI) dihilangkan } \\
\text { (andragogi, untuk } \\
\text { kebutuhan praktis) } \\
\text { b. Kesalahan ketik } \\
\text { c. Mengganti istilah yang } \\
\text { digunakan dalam } \\
\text { sintaks }\end{array}$ & $\begin{array}{l}\text { Layak } \\
\text { digunakan } \\
\text { dengan } \\
\text { revisi }\end{array}$ & $\begin{array}{l}\text { a. Menghilangkan KI, } \\
\text { langsung pada } \\
\text { tujuan praktis } \\
\text { b. Memperbaiki } \\
\text { kesalahan ketik } \\
\text { c. Mengganti istilah } \\
\text { pembelajaran dan } \\
\text { komunikasi }\end{array}$ \\
\hline Handout & $\begin{array}{l}\text { Validasi } \\
\text { Rata-rata } \\
(\mathrm{VR})= \\
86,19 \text { (baik } \\
\text { sekali) }\end{array}$ & $\begin{array}{l}\text { a. Memperjelas istilah } \\
\text { mikroorganisme } \\
\text { b. Memperbaiki } \\
\text { kesalahan ketik } \\
\text { c. Melengkapi daftar } \\
\text { pustaka } \\
\text { d. Mengatur peletakan } \\
\text { gambar } \\
\end{array}$ & $\begin{array}{l}\text { Dapat } \\
\text { digunakan } \\
\text { dengan } \\
\text { revisi }\end{array}$ & $\begin{array}{l}\text { a. Mengganti istilah } \\
\text { mikroorganisme } \\
\text { b. Kesalahan ketik } \\
\text { telah diperbaiki } \\
\text { c. Daftar pustaka telah } \\
\text { dilengkapi } \\
\text { d. Peletakan gambar } \\
\text { telah diperbaiki } \\
\end{array}$ \\
\hline
\end{tabular}

TABEL 2. Penilaian Handout

\begin{tabular}{|c|c|c|c|}
\hline No & Aspek yang dinilai & $\frac{\text { Rerata }}{\%}$ & Kategori \\
\hline & A. Komponen Hand Out: & & \\
\hline 1 & Materi pelatihan & 80 & Baik \\
\hline 2 & Ilustrasi gambar yang berkaitan & 86.67 & Sangat baik \\
\hline \multirow[t]{2}{*}{3} & Daftar pustaka & 73.33 & Baik \\
\hline & Penulisan Hand Out: & & \\
\hline 1 & Kebenaran konsep & 93.33 & Sangat baik \\
\hline 2 & Kemutakhiran isi & 86.67 & Sangat baik \\
\hline 3 & Membangkitkan minat/rasa ingin tahu & 80 & Baik \\
\hline 4 & $\begin{array}{l}\text { Sesuai dengan taraf berpikir dan kemampuan membaca } \\
\text { peserta pelatihan }\end{array}$ & 80 & Baik \\
\hline 5 & Mendorong peserta terlibat aktif & 73.33 & Baik \\
\hline 6 & Menggunakan bahasa Indonesia yang baik dan benar & 93.33 & Sangat baik \\
\hline 7 & Istilah yang digunakan tepat dan dapat dipahami & 86.67 & Sangat baik \\
\hline 8 & Hand out disertai ilustrasi gambar yang bermutu & 93.33 & Sangat baik \\
\hline 9 & $\begin{array}{l}\text { Ilustrasi atau gambar menggunakan tata letak yang } \\
\text { efektif }\end{array}$ & 86.67 & Sangat baik \\
\hline 10 & Menggunakan simbol atau istilah secara ajeg & 93.33 & Sangat baik \\
\hline 11 & $\begin{array}{l}\text { Hand out dapat memedomani peserta pelatihan dan } \\
\text { instruktur dalam pelatihan }\end{array}$ & 100 & Sangat baik \\
\hline & $\begin{array}{c}86.19 \\
\text { Sangat baik } \\
\end{array}$ & & \\
\hline
\end{tabular}

\section{Hasil Uji Coba:}

1. Kepraktisan model

a. Ketercapaian sintak oleh instruktur

Pada pertemuan 1 (materi) terdapat 3 sintaks, yaitu kegiatan awal, kegiatan inti dan kegiatan penutup. Secara keseluruhan ketercapaian sintaks pada pertemuan 1 adalah baik sekali dengan pencapaian nilai 4,11. Pada pertemuan pembinaan dan praktik (pertemuan 2, 3, 4, dan 5), rata-rata nilai kegiatan praktik adalah 3,995, dan rata-rata nilai untuk pertemuan 1 sampai dengan 5 adalah 4,05 atau dalam katagori baik sekali. Kegiatan inti pada pertemuan 1 telah dilakukan dengan baik. Kegiatan inti yang dilakukanantara lain menonton film kejadian penyakit akibat makanan yang terjadi pada makanan yang dijual di foodcourt 
Singapura. Durasi film ini 20 menit, yang menyajikan sebab munculnya penyakit dan akibat yang ditimbulkannya. Peserta pelatihan merasa tertarik dengan adanya film, dengan menonton hiburan tetapi sebenarnya adalah belajar. Sesuai dengan pendapat Thierauf [18] bahwa orang mempertahankan sekitar $25 \%$ dari apa yang mereka dengar, $45 \%$ dari apa yang mereka lihat, dan $70 \%$ dari apa yang mereka lihat, dengar, dan lakukannya. Selama ini mereka belum pernah mendapatkan pembelajaran dengan menonton film.

Kegiatan menonton film atau video mengenai kejadian penyakit akibat makanan ini dapat menyentuh peserta pelatihan dari sisi kognitif dan afektifnya, sehingga peserta pelatihan tergugah hatinya untuk mau, berniat dan akhirnya melakukan perilaku higienis dalam pekerjaannya sehari-hari. Gambaran dari film tersebut memberikan wawasan dan pengetahuan mengenai pentingnya melakukan perilaku higienis sehingga meningkatkan keyakinan bahwa praktik higienis sebenarnya adalah suatu kewajiban, tidak merepotkan, sangat bermanfaat, tidak ada ruginya atau sangat baik untuk dilakukan dan membuat konsumen akhirnya menjadi senang. Dari sisi afektif, peserta pelatihan ditunjukkan kerugian yang timbul dan dirasakan oleh bisnisnya dan konsumen. Akibat makanan yang disediakan tidak dipersiapkan dengan higienis, maka banyak konsumen akhirnya sakit dan harus di rawat di rumah sakit. Selain harus mengeluarkan banyak uang untuk pengobatan, kerugian lain yang harus ditanggung adalah kehilangan nyawa. Akibat yang harus ditanggung pemilik usaha dan penjamah makanan adalah kehilangan mata pencahariannya, karena setelah melalui pemeriksaan atau investigasi akhirnya pengawas kesehatan lingkungan harus menutup usaha penjualan makanan tersebut.

Pada kegiatan selanjutnya, instruktur mengajak berdiskusi dengan mengajukan pertanyaan apa penyebab, efek merugikan dan upaya yang harus dilakukan untuk mencegah kejadian tersebut. Instruktur lebih berperan sebagai fasilitator, mengatur jalannya diskusi. Peserta pelatihan secara bergantian menyampaikan pendapatnya dan terakhir instrukstur akan menyimpulkan. Kegiatan selanjutnya adalah mengumpulkan informasi, yaitu menyampaikan materi yang telah dipersiapkan sebelumnya. Untuk mempermudah penyampaian materi, materi dikemas dalam power point yang dilengkapi dengan gambar untuk memperjelas keterangan. Disela-sela menjelaskan materi tersebut, instruktur juga melakukan umpan balik, dengan memberikan pertanyaan untuk di jawab oleh peserta pelatihan. Hal ini dillakukan untuk mengecek pemahaman peserta pelatihan. Di samping itu, peserta pelatihan juga ada yang memberikan pertanyaan atau tanggapan.

Kegiatan penutup telah dilakukan dengan baik sekali. Di akhir pertemuan, instruktur bersama dengan peserta pelatihan menyimpulkan materi yang telah disampaikan dan sekaligus memberikan pengarahan kegiatan praktik yang akan dilakukan pada pertemuan berikutnya. Untuk kegiatan praktik tersebut, peserta pelatihan akan dibagi menjadi 4 kelompok kecil sesuai dengan tempat atau lokasi standnya. Masing-masing kelompok akan diwakili oleh 8-9 penjamah makanan. Dengan bantuan lembar observasi ketrampilan atau praktik higienis, masing-masing peserta harus melakukan observasi praktik higienis teman penjamah yang lain. Kegiatan ini ditujukan agar mereka mau melakukan dan sekaligus mengetahui praktik yang dilakukannya telah sesuai atau belum dengan bantuan observasi orang lain. Observasi dilakukan pada waktu yang tidak ditentukan, dan hasilnya dicatat pada lembar yang telah disediakan. Hasil observasi akan dilaporkan atau dipresentasikan pada pertemuan berikutnya. Ketrampilan praktik higienis yang kurang baik, akan dievaluasi dan dipraktikkan secara langsung di tempat kerja. Dalam rangka memberikan motivasi, kepada masing-masing penjamah makanan diberikan 2 buah celemek yang bertuliskan identitas foodcourt dengan warna yang berbeda. Terakhir instruktur menutup pertemuan dengan 
berpamitan dan mengucapkan salam. Nilai ketercapaian sintaks pada pertemuan 1 adalah baik sekali dengan pencapaian nilai 4,11 .

Pada pertemuan pembinaan dan praktik (pertemuan 2, 3, 4, dan 5), rata-rata nilai kegiatan praktik adalah 3,995, dan rata-rata nilai untuk pertemuan 1 sampai dengan 5 adalah 4,05 atau dalam katagori baik sekali. Kegiatan pembinaan dan praktik dilakukan di foodcourt pada hari aktif, agar melihat langsung praktik higienis yang dilakukan. Kegiatan pada masingmasing pertemuan adalah sama, tetapi berbeda berdasarkan hasil observasi praktik yang dilakukan. Melengkapi hasil observasi praktik higienis teman sejawat, instruktur tanpa sepengetahuan peserta pelatihan atau penjamah makanan melakukan observasi tersendiri untuk kegiatan yang dilakukan oleh masing-masing stand. Hasil observasi akan ditunjukkan atau dibacakan, hal ini dilakukan untuk memicu semangat dan kemauan peserta pelatihan untuk merubah atau meningkatkan perilaku higienisnya. Diakhir kegiatan, selain menyimpulkan kegiatan pelatihan, instruktur akan memberikan penghargaan atas kinerja yang baik kepada peserta pelatihan dengan pujian. Dan sekali lagi ditekankan untuk senantiasa melakukan perilaku higienis di tempat kerja

b. Partisipasi

Adapun aktivitas peserta pelatihan pada kegiatan penyampaian materi menunjukkan bahwa aktivitas yang paling banyak dilakukan oleh peserta pelatihan adalah mendengarkan atau memperhatikan penjelasan instruktur dan melakukan praktik $(67,19 \%)$, selanjutnya dalah membaca handout (16,6\%), berdiskusi $(8,3 \%)$, dan melakukan kegiatan menulis serta melakukan aktivitas yang tidak terkait dengan kegiatan pelatihan, misal bercanda dengan teman, makan/minum, melamun, dan sebagainya (3,95\%).

Tidak semua peserta pelatihan konsentrasi untuk mendengarkan atau mendengarkan penjelasan instruktur. Kegiatan paling menarik perhatian adalah menonton film, karena terdapat cerita dan gambar hidup yang diikuti jalan ceritanya. Sebagian peserta pelatihan menyelingi mendengarkan materi dengan membaca handout. Hal ini dilakukan diduga karena merasa tertarik dengan handout yang dibagikan atau berusaha mencari kejelasan materi yang disampaikan oleh instruktur. Sesuai dengan karakteristik orang dewasa, hanya sedikit sekali yang melakukan aktivitas atau kegiatan mencatat yang diperlukan. Dan sebagian kecil lainnya karena kelelahan akhirnya mengantuk atau berbicara dengan teman didekatnya.

c. Respon peserta pelatihan

Respon peserta pelatihan terhadap pelaksanaan pelatihan ini adalah senang (89\%). Sebagian besar peserta pelatihan menjadi senang karena buku yang dibagikan mudah untuk dipelajari di samping ada alasan yang lain, sedangkan harapan atau pendapat dari peserta pelatihan adalah pelatihan ini dapat dilaksanakan secara berkala dan buku yang diberikan mempunyai bahasa yang mudah dipahami. Dengan metode pelatihan yang berbeda (menonton film, diskusi/tanya jawab, ceramah, dan praktik langsung) peserta pelatihan merasakan senang dan berharap pelatihan bisa dilakukan kembali secara berkala. Kombinasi metode pembelajaran atau pelatihan, seperti ceramah, diskusi/tanya jawab, melihat film, dan praktik langsung dapat memberikan pengalaman yang baru pada orang dewasa [19].

2. Keefektifan model

a. Tes pengetahuan

Rata-rata terdapat peningkatan nilai bila dibandingkan sebelum dan setelah diberikan pelatihan. Untuk materi tes kebersihan tangan dan penggunaan alat pengambil makanan menunjukkan hasil yang baik sekali. Nilai tersebut menunjukkan bahwa penjamah makanan 
memiliki pengetahuan yang baik bahkan sebelum diberikan pelatihan, kecuali untuk materi pencegahan kontaminasi silang dengan penggunaan baju kerja atau celemek. Tingkat pengetahuan menunjukkan bahwa sebelum pelatihan cukup baik, tetapi setelah diberikan pelatihan, nilainya menjadi baik sekali yang artinya setelah diberikan pelatihan pengetahuannya menjadi semakin baik. Hasil uji t 2 sampel berpasangan menunjukkan mean pengetahuan setelah pelatihan (post) lebih tinggi dibandingkan dengan mean sebelum (pre) pelatihan. Hal ini menunjukkan bahwa setelah pelatihan pengetahuan penjamah makanan menjadi lebih tinggi dibandingkan dengan sebelum pelatihan. Hasil uji t 2 sampel berpasangan juga diperoleh nilai $-21,083(\mathrm{p}=0,001(<0,05))$ yang berarti terdapat perbedaan yang signifikan antara pre-post test yang telah dilakukan atau pelatihan memberikan dampak terhadap pengetahuan higiene penjamah makanan. Stimulus akan mempengaruhi sistem kognisi, baik memori short-term maupun memori long-term, sehingga mudah untuk dipelajari. Handout juga menjadi pegangan pada saat kegiatan pelatihan praktik higienis. Pada pertemuan ini, meskipun waktunya tidak lama, namun penjamah makanan diberikan kesempatan untuk bertanya dan melakukan praktik lebih banyak.

Pengetahuan merupakan hasil dari "tahu", dan ini terjadi setelah orang melakukan penginderaan terhadap suatu obyek tertentu. Seperti halnya yang dikemukakan oleh Bloom, tingkatan pengetahuan yang tercakup dalam domain kognitif yang mempunyai 6 tingkatan [20]. Pemberian materi dengan contoh kasus (film), ceramah, diskusi, tanya jawab, dan praktik langsung mengenai praktik berperilaku higienis dalam beberapa kali tatap muka, dimaksudkan untuk mencapai tingkatan pengetahuan dan keterampilan yang paling baik. Pertanyaan yang awalnya tidak dapat dijawab oleh peserta pelatihan, setelah pelatihan ternyata dapat dijawab dengan benar. Pengetahuan yang diperoleh peserta paling tidak telah mencapai tingkat pemahaman materi, yaitu kemampuan untuk menginterpretasikan atau mengulang informasi yang diperoleh.

Pengetahuan mencakup ingatan terkait hal yang pernah dipelajari dan disimpan dalam ingatan karena waktu pengambilan data terkait pengetahuan tidak terlalu lama dengan pelaksanaan pelatihan, maka ingatan mereka masih baik. Menurut Winkel [21], pada umumnya, seseorang setelah belajar pertama kali, lupa dengan cepat, tetapi kemudian tidak begitu cepat. Gejala ini berkaitan dengan apa yang dikenal sebagai "kurva lupa Ebbinghaus", yaitu pada permulaan retensi berkurang dengan cepat, tetapi kemudian pengurangan itu berangsur-angsur mengecil. Ebbinghaus juga menekankan bahwa pengetahuan atau apa yang dipelajari oleh seseorang secara logaritmik akan cenderung menurun dari waktu ke waktu. Demikian pula dengan pernyataan Anderson dalam Suryana [22], semakin lama ingatan akan semakin berkurang. Dalam satu bulan, maka ingatan untuk suatu pengetahuan hanya tersisa $18 \%$. Penyampaian pelatihan dengan metode tersebut (teori, belajar memecahkan masalah, praktik, dan pendampingan) dimaksudkan agar penyerapan informasi oleh peserta pelatihan menjadi maksimal. Hal ini sesuai dengan Prawiradilaga [23] bahwa penyerapan informasi dengan membaca mencapai 10\%, mendengar 20\%, mendengar dan melihat 50\%, mengatakan $70 \%$ dan mengatakan dan melakukan 90\%. Dalam pelatihan ini, peserta pelatihan banyak diajak untuk berdiskusi, menjelaskan kembali, dan melakukan praktik secara langsung dengan cara yang benar, sehingga penyerapan informasinya diharapkan mencapai $90 \%$.

Sesuai dengan yang dipaparkan oleh WHO [24] bahwa pengetahuan dapat diperoleh dari pengalaman, guru, orang tua, buku atau media masa. Riben et al., [25] menunjukkan bahwa pelatihan telah berdampak pada hasil tes pengetahuan dalam jangka pendek. Pesan dalam pelatihan dapat disampaikan dengan optimal karena pelatihan dilakukan sesuai dengan 
karakteristik penjamah makanan dan dilakukan langsung di tempat kerjanya. Beberapa peneliti seperti Rennie [26], dan Taylor [27], telah berusaha untuk mengidentifikasi faktor kunci dari program pelatihan yang efektif. Pelatihan di tempat kerja adalah salah satu faktor kunci tersebut

b. Sikap

Terdapat peningkatan mean rata-rata sikap-konsekuensi dan evaluasi sebelum dan setelah pelatihan atau mean rata-ratanya setelah pelatihan (post) lebih tinggi dibandingkan dengan mean rata-rata sikap sebelum (pre) pelatihan. mean sikap-konsekuensi dan evaluasi berperilaku higienis setelah pelatihan (post) lebih tinggi dibandingkan dengan mean sebelum (pre) pelatihan. Hasil uji t 2 sampel berpasangan terhadap sikap konsekuensi dan evaluasi adalah signifikan $(\mathrm{p}=0,001(<0.05))$ yang berarti terdapat perbedaan yang signifikan pada variabel sikap sebelum dan setelah pelatihan dilakukan atau pelatihan memberikan dampak terhadap peningkatan sikap penjamah makanan.

Sikap mengenai perilaku higienis penjamah makanan yang ada di Foodcourt Baseball kampus Unesa Ketintang Surabaya sesuai dengan hasil analisis pengujian awal, menunjukkan bahwa semakin tinggi pengetahuannya maka semakin tinggi pula sikapnya, dan semakin tinggi sikap maka semakin tinggi pula niat untuk melakukan perilaku atau praktik higienis. Selanjutnya dengan niat yang tinggi akan semakin tinggi pula penjamah makanan dalam melakukan praktik higienis dalam tugasnya sehari-hari. Pengetahuan merupakan faktor kunci pembentukan sikap penjamah makanan, sehingga pada akhirnya akan berpengaruh kepada pembentukan niat dan praktik higienis. Hal ini sejalan dengan penelitian Chan [28] dan Junaedi [29] yang menyimpulkan bahwa pengetahuan memiliki hubungan yang positif dengan sikap. Hal ini terjadi karena semakin banyak informasi yang dimiliki oleh orang, maka orang tersebut semakin selektif dalam bersikap [30].

Sikap penjamah makanan mengenai praktik higienis meliputi keyakinan akan konsekuensi dan evaluasi secara positif atau negatif tentang perilaku higienis. Kosekuensi menunjukkan bahwa apabila penjamah makanan melakukan perilaku atau praktik higienis seperti mencuci tangan, memakai celemek dan menggunakan alat pengambil makanan adalah tidak merepotkan dan bermanfaat untuk menjaga kebersihan Agar suasana pelatihan dapat meningkatkan gairah belajar dan terutama maningkatkan sikap dan kepercayaan peserta pelatihan, maka pelatihan dilakukan dengan 2 tahap, tahap pertama (pertemuan pertama) adalah pemberian materi dan diskusi. Pada tahap kedua (pertemuan ke 2 sampai 5) dilakukan observasi antar teman sejawat dan praktik langsung serta diskusi atau tanya jawab. Pada pertemuan pertama, setelah membuka pelatihan (menyampaikan apersepsi dan motivasi serta penyampaian tujuan belajar) diputarkan film kejadian nyata di Singapura mengenai kasus kejadian penyakit akibat makanan oleh penjual makanan jajanan.

Penggunaan media seperti film atau video dianggap dapat menyampaikan pesan atau pengetahuan dan penjamah makanan mendapatkan informasi tersebut. Hal lainnya adalah dengan menonton film, berfungsi mempengaruhi jalan pikiran dan merubah sikap dan tingkah laku penjamah makanan untuk mau melakukan praktik higienis dalam pekerjaannya sehari-hari, sepertihalnya yang disampaikan oleh Effendy [31].

c. Praktik hgiene

Praktik higienis sebelum pelatihan secara umum mempunyai kategori yang cukup baik $(2,69)$, sedangkan setelah pelatihan menunjukkan ada peningkatan, yaitu menjadi sangat baik $(4,07)$. Pada umumnya, praktik higienis berada pada kategori cukup baik sebelum pelatihan dilakukan. Setelah pelatihan, secara keseluruhan praktik higienis berada pada kategori baik. Namun yang terlihat menonjol peningkatannya adalah praktik higienis terkait kegiatan 
mengambil makanan dengan alat pengambil khusus makanan. mean praktik higienis setelah pelatihan (post) lebih tinggi dibandingkan dengan mean sebelum (pre) pelatihan. Hal ini menunjukkan bahwa pelatihan dapat meningkatkan praktik higienis penjamah makanan. Hasil uji t 2 sampel berpasangan juga diperoleh nilai $t=-19,483(p=0,001(<0,05))$ yang berarti terdapat perbedaan yang signifikan antara pre-post test terkait praktik higienis atau pelatihan memberikan dampak terhadap praktik higienis penjamah makanan. Metode pelatihan yang diterapkan pada penjamah makanan di foodcourt Baseball kampus Unesa Ketintang Surabaya dapat meningkatkan keterampilan atau praktik higienis penjamah makanan, karena dengan kombinasi metode pembelajaran atau pelatihan, seperti ceramah, diskusi/tanya jawab, melihat film, dan praktik langsung dapat memberikan pengalaman yang baru pada orang dewasa [19]. Hal ini sesuai dengan pendapat Georgakopoulos [32], bahwa untuk membentuk pengalaman belajar yang baik, maka dalam sebuah program pelatihan harus menggabungkan praktik langsung di lapangan, tutorial, penyampaian materi singkat, workshop.

Program pelatihan ini dirancang sesuai dengan kebutuhan dan karakteristik penjamah makanan yang ada di foodcourt Baseball kampus Unesa Ketintang Surabaya. Program pelatihan yang memanfaatkan berbagai teknik instruksional, seperti yang ditunjukkan oleh Kolb [33] bahwa sangat penting untuk belajar secara efektif. Pendapat tersebut diperkuat oleh Thierauf [34] dan diperjelas dengan hasil penelitian yang menunjukkan terdapat perbedaan yang sangat signifikan atau pelatihan memberikan dampak terhadap praktik higienis pada penjamah makanan. Berdasarkan ketercapaian sintaks dalam pembelajaran menunjukkan hasil bahwa pelatihan dilakukan dengan baik sehingga tujuan pelatihan akan tercapai. Sesuai dengan pendapat Green [35], bahwa intervensi kesehatan makanan dengan memberikan pengetahuan kepada penjamah makanan dengan harapan penjamah makanan akan menerjemahkan pengetahuan ke dalam praktik. Terlihat jelas pada hasil observasi praktik higienis setelah dilakukan pelatihan yang menunjukkan adanya peningkatan.

\section{KESIMPULAN}

1. Evaluasi kepraktisan model diperoleh model pelatihan yang memenuhi kriteria sangat valid $(4,28)$ dan layak digunakan, serta handout dengan kriteria baik sekali $(86,19 \%)$;

2. Hasil penilaian aktifitas instruktur baik sekali dan $96 \%$ peserta pelatihan mengikuti kegiatan pelatihan dengan baik; $89 \%$ peserta pelatihan memberikan respon senang terhadap kegiatan pelatihan; Pelatihan secara signifikan efektif terhadap peningkatan pengetahuan, praktik berperilaku higienis, dan sikap penjamah makanan. 


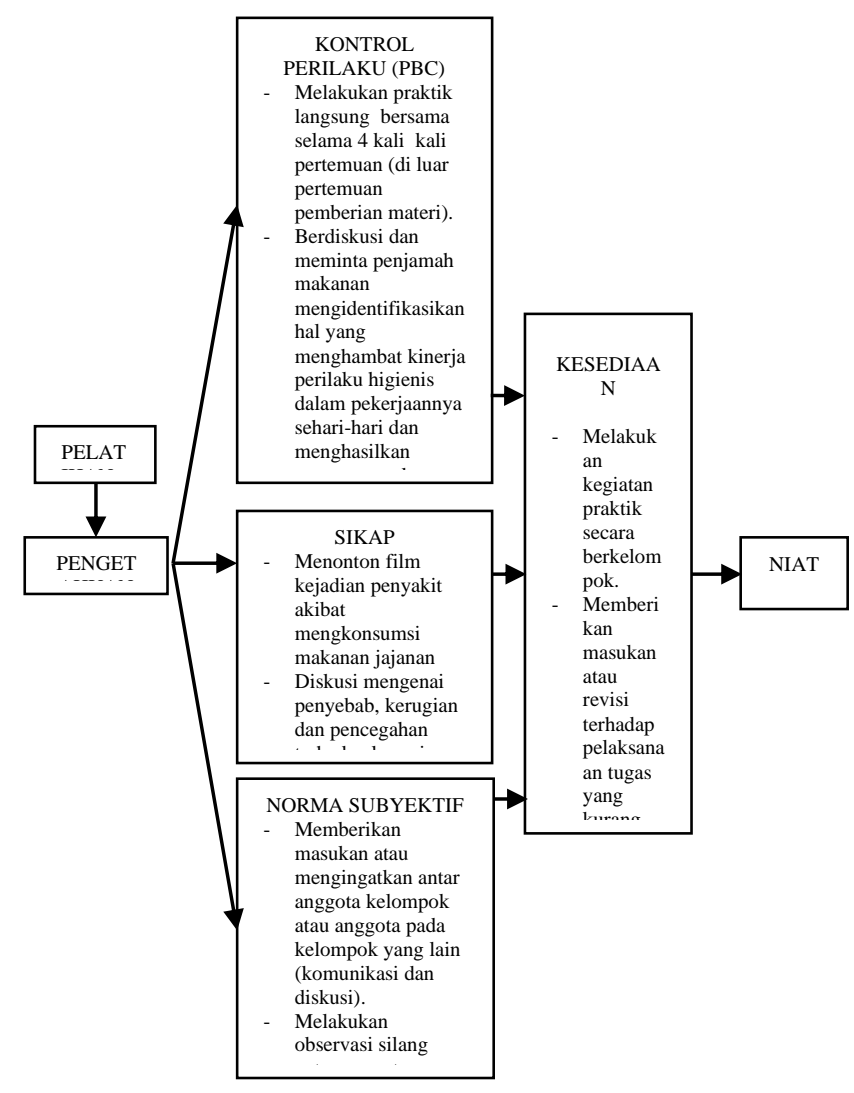

\section{REFERENSI}

[1] National Health and Medical Research Council (NHMRC). 2003. NHMRC Dietary Guidelines for Australian Adults. A Guide to Healthy Eating. Melburne: National Health And Medical Research Council

[2] Green dan Selman, 2005; Green L.R., and Selman C. 2005. Factors Impacting Food Workers' and Managers' Safe Food Preparation Practices: A Qualitative Study. Food Protection Trends, 25 (12), 981-990

[3] Hennessy T.W., Baggett H.C., Rudolph K., Bruden D., Reasonover A., Parkinson A. 2004. Community-Onset Methicillin-Resistant Staphylococcus aureus Associated With Antibiotic Use and The Cytotoxin Panton-Valentine Leukocidin During a Furunculosis Outbreak In Rural Alaska. Journal Infect Dis. 189:1565-1573

[4] Mead P.S., Slutsker L., Dietz V., McCaig L.F., Bresee J.S., Shapiro C., Griffin P.M., Tauxe R.V. 1999. Food-Related Illness and Death In The Unites States. Journal Emerg Infect Dis. Vol. 5(5), Sept-Oct 1999: 607-625

[5] Isara A.R., and Isah E.C. 2009. Knowledge And Practice of Food Hygine and Safety Among Food Handlers in Fast Food Restaurants in Benin City, Edo State, Niger. Postgraduate Medical Journal, September, 16(3): 207-212

[6] Santosh M.J., Moiyadi A.V., Satish S., Rao G. 2008. Multicompartmental Trigeminal Schwannoma--a Clinical Report. The Journal of Craniofacial Surgery. 2008. 19: 11771180

[7] Laporan Tahunan BPOM RI 2017

[8] Olsen G.W., Burris J.M., Mandel J.H., Zobel L.R. 2000. Serum Perfluorooctane Sulfonate and Hepatic and Lipid Clinical Chemistry Tests in Fluorochemical Production Employees. Journal Occup Environ Med; 41(9):799-806

[9] Friedman S.R., Reynolds J., Quan M.A., Call S., Crusto C.A., and Kaufman J.S. 2007. 
Measuring Changes in Interagency Collaboration: An Examination of The Bridgeport Safe Start Initiative. Evaluation And Program Planning, 30(3): 294-306

[10] Kassenborg H.D., Smith K.E., Vugia D.J. 2004. Fluoroquinolone-Resistant Campylobacter Infections: Eating Poultry Outside Of The Home and Foreign Travel Are Risk Factors. Emerging Infections Program Food Net Working Group. Clin Infect Dis Journal. 2004, 38 (Suppl 3): 279-284

[11] Laporan Tahunan BPOM, 2019

[12] FDA Food Code. 2009. Supplement to the 2009 Food Code. U. S. Department of Health And Human Services. Public Health Service Food and Drug Administration

[13] Tamaroh S. 2002. Knowledge, Practices and Attitude on Food Safety of Food Handlers in Catering Establishmen in Yogjakarta. Dibawakan pada Seminar Nasional PAPTI, Malang, Indonesia, 30-31 Juli 2002

[14] Guzewich J., and Ross M.P. 1999. Evaluation of Risks Related to Microbiological Contamination of Ready-To-Eat Food by Food Preparation Workers and The Effectiveness of Interventions to Minimize Those Risks. http://www. fda.gov/Food/FoodSafety/RetailFoodProtection/ucm210138.htm (sitasi 12 Agustus 2012)

[15] Motarjemi Y., and Kaferstein F. 1999. Food Safety, Hazard Analysis and Critical Control Point and The increase In Food Borne Diseases: a Paradox?. Food Control Journal. Vol. 10: 325-333

[16] Pilling V.K., Brannon L.A., Shanklin C.W., Howells A.D., and Roberts K.R. 2008. Identifying Specific Beliefs to Target to Improve Restaurant Employees' Intentions for Performing Three Important Food Safety Behaviors. American Dietetic Association. Vol. 108 (6): 991-997

[17] Clayton D.A., and Griffith C.J. 2008. Efficacy of an Extended Theory of Planned Behaviour Model for Predicting Caterers' Hand Hygiene Practices. International Journal of Environmental Health Research, 18 (2): 83-98

[18] Thierauf R.J. 1995. Virtual Reality Systems For Business. USA: Quorum Books

[19] Asmin. 2000. Konsep dan Metode Pembelajaran Untuk Orang Dewasa. http://file.upi.edu/Direktori/FIP/JUR._PEND._LUAR_SEKOLAH/19510 9141975011-AYI_OLIM/andragogi_PDF2.pdf >

[20] Notoatmodjo S. 2003. Prinsip - Prinsip Dasar Ilmu Kesehatan Masyarakat. Jakarta: Rineka Cipta

[21] Winkel W.S. 1999. Psikologi Pengajaran. Jakarta: Grasindo

[22] Suryana A. 2006. Panduan Praktis Mengelola Pelatihan. Jakarta : EDSA Mahkota

[23] Prawiradilaga D.S. 2009. Prinsip Desain Pembelajaran. Jakarta : Prenada Media Group

[24] WHO, 1992

[25] Riben P.D., Mathias R.G., Wiens M., Cocksedge W., Hazelwood A., Kirshner B., Pelton J. 2004. Routine Restaurant Inspections and Education of Food Handlers: Recommendations Based on Critical Appraisal of The Literature and Survey of Canadian Jurisdictions on Restaurant Inspections and Education of Food Handlers. Can Journal Public Health. 1994 Jul-Aug;85 (Suppl 1):S67-S70

[26] Rennie D.M. 1994. Evaluation of Food Hygiene Education. British Food Journal. Vol. 96 (11): 20-25

[27] Taylor A, Steven and Baker. 1994. An Assesment of the Relationship between Service Quality and Customer Satisfaction in The Information of Customers Purchase Intentions. Journal of Retailing. Vol.70(2):163-178

[28] Chan K. 1999. Market Segmentation of Green Consumers in Hongkong. Journal of International Consumer Marketing. Vl. 12(2): 7-24 
[29] Junaedi M.F.S. 2008. Analisis Faktor Demografi, Akses Media dan Sumber Informasi Terhadap Kepedulian dan Kesadaran Lingkungan Konsumen: Kajian Pemasaran Berwawasan Sosial. Kinerja. Vol. 7: 96-111

[30] Setiadi N. 2010. Perilaku Konsumen: Perspektif Kontemporer Pada Motif, Tujuan dan Keinginan Konsumen. Jakarta: Kencana Prenada Media

[31] Effendi, 1997

[32] Georgakopoulos G., Ciancanelli P., Coulson A., and Kaldis. 2008. Stewardship and Risk: an Empirically Grounded Theory of Organic Fish Farming in Scotland. The Agricultural Economics Review, Vol. 9(2): 16 - 30

[33] Kolp D.A. 1984. Experiential Learning-Experience as a Source of Learning and Development. UK: Prentice Hall

[34] Thierauf R.J. 1995. Virtual Reality Systems For Business. USA: Quorum Books

[35] Green L.R., Radke V., Mason R., Bushnell L., Reimann D.W., Mack J.C., Motsinger M.D., Stigger T., and Selman C.A. 2007. Factor Related to Food Worker Hand Hygiene Practises. Journal of Food Protection, 2007, vol. 70 (3): 661-666 